\title{
Perubahan Tutupan Lahan Akibat Ekspansi Perkebunan Kelapa Sawit: Dampak Sosial, Ekonomi dan Ekologi
}

\author{
Rizka Amalia ${ }^{1}$, Arya Hadi Dharmawan², Lilik B. Prasetyo ${ }^{3}$, Pablo Pacheco ${ }^{4}$ \\ 1Program Studi Sosiologi Pedesaan IPB; e-mail: amalrizka@apps.ipb.ac.id \\ ${ }^{2}$ Fakultas Ekologi Manusia IPB \\ ${ }^{3}$ Fakultas Kehutanan IPB \\ ${ }^{4} \mathrm{WWF}$
}

\begin{abstract}
ABSTRAK
Perkebunan kelapa sawit berdampak negatif pada aspek-aspek lingkungan, sosial dan ekonomi komunitas lokal. Melalui peningkatan system tata kelola perkebunan kelapa sawit maka dapat mengurangi dampak negatif tersebut. System tata kelola seperti sertifikasi dan standar-standar keberlanjutan diinisiasi oleh produser, distributor, pemerintah, akademisi, pasar internasional dan LSM. Sistem tata kelola ini dapat mencakup skala global atau nasional. Indonesia telah mengimplementasikan system tata kelola yang berskala global dan nasional namun belum semua perusahaan perkebunan kelapa sawit dan smallholder mengimplementasikanya. Oleh karena itu, sistem tata kelola tersebut belum berhasil menurunkan dampak negatif ekspansi perkebunan kelapa sawit. Konflik sosial masih sering terjadi akibat dari kebakaran hutan dan pencemaran lingkungan. Di Kutai Kartanegara, Kalimantan Timur, Indonesia, ekspansi perkebunan kelapa sawit terjadi secara cepat dimana ekspansi tersebut ada yang tidak menerapkan sistem tata kelola perkebunan kelapa sawit. Menggunakan metode survey dan wawancara mendalam, penelitian ini bertujuan mengukur dampak ekspansi perkebunan kelapa sawit pada kerentanan ekologi, sosial dan ekonomi. Hasil penelitian ini mengindikasikan bahwa (1) RSPO dan ISPO belum bisa menekan deforestasi akibat ekspansi perkebunan kelapa sawit; (2) Walaupun RSPO dan ISPO diimplementasikan, masih tetap terjadi konflik sosial, kerentanan ekologi dan ekonomi pada komunitas lokal.
\end{abstract}

Kata kunci: Sistem tata kelola, Indonesia, smallholder, ISPO, Perkebunan Kelapa Sawit, RSPO

\begin{abstract}
Oil palm plantations have negative impact on environment, social and economic of local communities. Improving oil palm plantation governance systems can help mitigate some of these impacts. Governance systems, such as certification and sustainability standards are initiated by producers, distributors, governments, academics, international markets, and NGOs. They can be global or national, and both have been implemented in Indonesia in some, but not all, estate company and smallholder grower systems. Despite some degree of implementation, these governance system have had limited success in minimize the negative impacts of oil palm expansion. Social conflicts are still occurring, as are forest fires and environmental pollution.In Kutai Kartanegara, East Kalimantan, Indonesia, oil palm plantations are expanding rapidly that there are oil palm expansion without implementing oil palm governance system. Using survey methods and in-depth interviews, we assessed the impact of oil palm expansion on their ecological,social, and economic vulnerabilities. Our results indicated that (1) RSPO and ISPO have not reduces the rate of deforestation; (2) RSPO and ISPO have been implemented, social conflicts, economic and ecologies vulnerabilities to local communities remain
\end{abstract}

Keywords: Governance system, Indonesia, smallholder, ISPO, Oil Palm Plantation, RSPO

Citation: Amalia, R, Dharmawan, A.H., Prasetyo L.B., Pacheco P.(2019). Perubahan Tutupan Lahan Akibat Ekspansi Perkebunan Kelapa Sawit: Dampak Sosial, Ekonomi dan Ekologi. Jurnal Ilmu Lingkungan, 17(1), 130-139, doi:10.14710/jil.17.1.130-139

\section{Latar Belakang}

Kelapa sawit merupakan komoditas penting di pasar lokal, regional dan global karena produkproduk turunannya digunakan sebagai minyak goreng, bahan baku margarin, bahan baku industri kosmetik (Kementrian Perindustrian RI 2007), campuran es krim, saus salad, keju, coklat, pelumas, biodiesel dan bahan biogas (Khatun et al
2017). Oleh karena itu, banyak pengusaha sawit seperti perusahaan perkebunan kelapa sawit milik swasta dan petani kelapa sawit di Indonesia melakukan ekspansi perkebunan kelapa sawit untuk memenuhi permintaan pasar.

Ekspansi perkebunan kelapa sawit tidak hanya dilakukan oleh perusahaan perkebunan kelapa sawit, namun juga petani kelapa sawit. 
Perusahaan perkebunan kelapa sawit selama ini mengekspansi kelapa sawitnya di area Hak Guna Usaha (HGU), sedangkan petani kelapa sawit mengekspansi perkebunan kelapa sawit di lahanlahan yang mereka miliki seperti belukar, ladang atau kebun. Selain itu, ada beberapa petani kelapa sawit mengekspansi perkebunan kelapa sawit di area-area hutan yang ada di sekitar tempat tinggal mereka. Ekspansi perkebunan kelapa sawit seharusnya dilakukan di Area Penggunaan Lain (APL) dan Kawasan Budidaya Non Kehutanan (KBNK), namunekspansi perkebunan kelapa sawit juga dilakukan di kawasan hutan dan taman nasional secara ilegal dan informal (Hidayah 2016) serta dilakukan di lahan gambut dan lahan mineral (Afriyani et al 2016). Bahkan, keberadaan perkebunan kelapa sawit di kawasan hutan di Indonesia sudah mencapai 2,7 juta ha (Info sawit 2017). Pada tahun 1990-2005 terdapat 56\% ekspansi perkebunan kelapa sawit berada di hutan primer, hutan sekunder dan hutan produksi (Koh dan Wilcove, 2008).Ekspansi perkebunan kelapa sawit di kawasan hutan mengakibatkan banyaknya area hutan yang hilang (Yunikartika R 2015), memicu deforestasi (setiawan et al 2016), menimbulkan erosi tanah (Lee et al 2012), serta fragmentasi habitat, hilangnya dan biodiversitas (Fitzherbert et al 2008). Ekspansi perkebunan kelapa sawit di kawasan hutan juga berdampak pada perubahan lanskap ekologi (Bennett et al 2018) dan perubahan tata guna lahan, perubahan tutupan lahan serta beberapa masalah lingkungan yang serius (Susanti dan Maryudi 2016).

Ekspansi perkebunan kelapa sawit berdampak transformasi nafkah rumahtangga (Mardianingsih et al., 2018). Ekspansi kelapa sawit tersebut meningkatan pendapatan pada level rumahtangga (Wicke et al 2011), namun peningkatan pendapatan yang hanya bertumpu pada dominasi usaha perkebunan kelapa sawitsehingga rumahtangga petani mengalami dilemanafkah karena rumahtangga petani kehilangan keberagaman sumber nafkahnya (Yulian et al 2017). Oleh karena itu, ekspansi perkebunan kelapa sawit tersebut menyebabkan kerentanan nafkah pada rumahtangga petani (Amalia 2016). Di sisi lain, ekspansi perkebunan kelapa sawit juga dapat meningkatkan devisa negara pada level nasional (Gapki 2017). Selain itu, ekspansi perkebunan kelapa sawit berdampak pada kondisi sosial suatu komunitas petani seperti timbulnya konflik (Koczberski dan Curry 2005) dan pergeseran pola hidup masyarakat yang semula subsisten menjadi berorientasi pada pasar (Zunariyah 2012).

Berbagai dampak negatif ekspansi perkebunan kelapa sawit terhadap lingkungan, ekonomi dan sosial; serta terjadinya ekspansi perkebunan kelapa sawit di kawasan hutan membuat produk kelapa sawit mempunyai citra yang jelek di pasar nasional dan internasional. Oleh karena itu,berbagai stakeholder dan 131 pemerintah pada skala nasional dan global berinisiasi untuk menerapan sistem tata kelola perkebunan kelapa sawitseperti IndonesianSustainable Palm Oil (ISPO) dan Roundtable on Sustainable Palm Oil (RSPO). ISPO diimplementasikan pada tahun 2011. ISPO bersifat wajib bagi perusahaan perkebunan kelapa sawit dan bersifat sukarela bagi petani kelapa sawit. RSPO diimplementasikan pada tahun 2004. RSPO bersifat sukarela bagi perusahaan dan petani kelapa sawit. Namun sampai saat ini, hanya sedikit proporsi minyak kelapa sawit yang telah mendapatkan sertifikat ISPO dan RSPO yaitu 9\% (ISPO 2017) dan 19\% (RSPO 2017). Sebagian besar sertifikasi ISPO dan RSPO dilakukan oleh perusahaan perkebunan kelapa sawit dan sedikit dilakukan oleh petani plasma serta petani mandiri. Berdasarkan hal tersebut maka tujuan dari penelitian ini yaitu:

1. mengidentifikasikecepatan ekspansi dan peran petani dalam perluasan perkebunan kelapa sawit,

2. menganalisis dampak ekonomi, sosial, dan ekologi akibat ekspansi perkebunan kelapa sawit serta kaitanya dengan implementasi tata kelola perkebunan kelapa sawit.

\section{Metode Penelitian}

Proses pengambilan data dilaksanakan pada pada 5-11 Februari 2017 dan tanggal 6-12 Juli 2017. Survey dilaksanakan di lokasi penelitian tersebut pada tanggal 14-28 Februari 2018. Penelitian ini dilakukan di Desa Gunung Sari, Kecamatan Tabang, Kabupaten Kutai Kartanegara, Provinsi Kalimantan Timur. Penelitian ini menggunakan paradigma post-positivistik dimana menggunakan kombinasi pedekatan kuantitatif dan kualitatif (Denzin dan Lincoln 2000). Pendekatan kuantitatif melalui survey menggunakan kuisioner pada 60 responden yang dipilih secara acak. Data yang digunakan dalam penelitian ini meliputi data primer dan data sekunder. Sementara itu, analisis tutupan lahan dilakukan dengan menggunakan data ground check, data peta batas administrasi Desa Gunung Sari, peta fungsi kawasan hutan Provinsi Kalimantan Timur, peta rupa bumi Indonesia Provinsi Kalimantan Timur skala 1: 50.0000,citra landsat 5 TM tanggal perekaman 12 Februari 1990, citra landsat 5 TM tanggal perekaman 14 Maret 1995, citra landsat 5 TM tanggal perekaman 24 Februari 2000, citra landsat 5 TM tanggal perekaman 17 September 2005, citra landsat 5 TM tanggal perekaman 11 Agustus 2009, dan cita landsat 8 OLI tanggal perekaman 8 Mei 2016.

\section{Hasil dan Pembahasan}

\subsection{Tipologi Petani di Desa Gunung Sari}

Terdapat tiga tipologi petani kelapa sawit berdasarkancara pengusahaan perkebunan kelapa sawit di Desa Gunung Sari yaitu: petani plasma, 
petani plasma yang mempunyai kebun kelapa sawit mandiri; dan petani mandiri.

1. Petani plasma merupakan petani kelapa sawit yang mengusahakan kelapa sawitnya dengan dukungan dana bank yang difasilitasi oleh perusahaan perkebunan inti sebagai kewajiban menaati aturan. Selain memfasilitas pendanaan, perusahaan ini juga membantu membukakan lahan (land clearing) untuk perkebunan kelapa sawit plasma. Pembukaan lahan tersebut dilakukan oleh perusahaan intimenggunakan alat berat seperti excavator. Kemudian, setelah perkebunan kelapa sawit petani plasma berbuah maka Tandan Buah Segar (TBS) wajib dijual ke perusahaan perkebunan kelapa sawit yang menjadi intinya. Luas perkebunan plasma rata-rata $2 \mathrm{Ha}$ per KK. Selain lahan perkebunan plasma, petani plasma juga memiliki lahan lain seperti ladang, kebun karet dan kebun buah. Sebagian kecil petani plasma mempertahankan lahan yang mereka miliki untuk bertanam buah, karet dan padi, sedangkan sebagian besar petani plasma lainnya berfikir rasional untuk meningkatkan ekonomi rumahtangga mereka dengan caramembuka lahan perkebunan secara mandiri di lahan yang mereka miliki dan yang mereka kuasai. Berdasarkan hal tersebut, maka muncul tipe petani kedua yaitu: petani plasma yang mempunyai perkebunan kelapa sawit mandiri.

2. Petani plasma yang mempunyai kebun mandirimerupakan petani kelapa sawit yang mempunyai plasma juga mengusahakan perkebunan kelapa sawit mandiri dengan cara membuka lahan dengan menggunakan censo atau membakar lahan secara terbatas dan memanfaatkan bantuan bibit dari pemerintah dan bantuan bibit dari perusahaan perkebunan kelapa sawit. Biasanya petani ini menjual TBS melalui empat cara alternatif yaitu (1) TBS dijual ke perusahaan dengan menjadi anggota koperasi; (2) TBS dijual ke perusahaan dengan menitipkan TBS ke anggota koperasi; (3) TBS dijual ke perusahaan dengan menitipkan TBS ke koperasi; (4)TBS dijual ke tengkulak. Lahan yang digunakan untuk ekspansi perkebunan kelapa sawit mandiri adalah lahan pertanian, kebun buah, hutan, lahan HGU, Hak Pengusahaan Hutan (HPH) dan konsesi perusahaan yang ada di sekitar Desa Gunung Sari dimana rata-rata luas kebun kelapa sawit mandiri mereka yaitu seluas 8,8 Ha. Selain memperluas perkebunan kelapa sawit secara mandiri, petani plasma yang mempunyai perkebunan kelapa sawit mandiri ini juga menambah lahan-lahan plasma mereka dengan cara membeli kebun plasma yang dimiliki oleh orang lain. Rata-rata kepemilikan kebun plasmanya seluas 2,9 Ha.Adanya proses jual beli lahan plasma tersebut kemudian menjadikan beberapa rumahtangga tidak mempunyaikebun plasma. Oleh karena itu, mereka berusaha mengekspansi lahan perkebunan secara mandiri. Di sisi lain, adanya pedatang dan orang lokal yang baru menikah juga tidak mempunyai plasma, sehingga mereka juga mengekspansi perkebunan kelapa sawit secara mandiri yang kemudian disebut sebagai petani mandiri.

3. Petani mandiri merupakan petani kelapa sawit yang mengekspansi perkebunan kelapa sawit menggunakan modal pribadi dengan cara membuka lahan dengan menggunakan censo atau membakar lahan secara terbatas dan memanfaatkan bibit pemerintah dan perusahaan perkebunan kelapa sawit dengan memanfaatkan lahan yang dibeli, lahan hutan, lahan HGU, HPH dan konsesi perusahaan yang ada di sekitar Desa Gunung Sari dimana rata-rata luas kebun kelapa sawit mandiri mereka yaitu seluas 3,5 Ha. Biasanya petani ini menjual TBS melalui empat cara alternatif yaitu (1) TBS dijual ke perusahaan dengan menjadi anggota koperasi; (2) TBS dijual ke perusahaan dengan menitipkan TBS ke anggota koperasi; (3) TBS dijual ke perusahaan dengan menitipkan TBS ke koperasi; (4)TBS dijual ke tengkulak.

Petani dengan tipe 1 (petani plasma) tidak mempunyai pilihan pasar karena mereka terikat secara struktural pada perkebunan kelapa sawit intinya. Sementara itu, petani tipe 2 dan tipe 3 mempunyai alternatif penjualan TBS yang sama. Keputusan pemilihan alternatif penjualan TBS tersebut akan berbeda pada setiap rumahtangga petani, tergantung kondisi sosial dan ekonomi yang dialami rumahtangga petani saat itu serta harga TBS pada saat itu. Dalam menentukan keputusan penjualan TBS petani selalu menimbang keuntungan (gain) dan kerungian (loss).

Perkebunan kelapa sawit yang diekspansi secara mandiri oleh petani plasma yang mempunyai perkebunan kelapa sawit mandiri dan petani mandiri, ada yang tidak dimitrakan dan ada yang dimitrakan ke perusahaan perkebunan inti melalui koperasi. Lahan perkebunan yang dimitrakan ke perusahaan perkebunan inti tersebut masih tetap ada yang tumpang tindih dengan Kawasan Budidaya Kehutana (KBK)seluas $206 \mathrm{Ha}, \mathrm{HGU}$ perusahaan perkebunan inti seluas $130 \mathrm{Ha}$, konsesi tambang seluas $46 \mathrm{Ha}$, dan $\mathrm{HPH}$ seluas 39 Ha. Berdasarkan hal tipologi petani, maka petani yang paling rasional secara ekonomi 
adalah petani plasma yang mempunyai kebun kelapa sawit mandiri.

\subsection{Ekspansi Perkebunan Kelapa Sawit Dan} Peran Petani Dalam Ekspansi Perkebunan Kelapa Sawit

RSPO telah diimplementasikan mulai dari tahun 2004, sedangkan ISPO telah diimplementasikan mulai dari tahun 2011. Namun, sejak kedua tata kelola perkebunan kelapa sawit diimplementasikan, tidak banyak perbaikan yang terjadi dalam pengusahaan dan managemen perkebunan kelapa sawit khususnya pada tingkat petani. Hal ini terjadi karena implementasi RSPO dan ISPO sampai saat ini bersifat sukarela untuk petani. Oleh karena itu, baik diimplementasikan atau tidak diimplementasikannya RSPO dan ISPO di Indonesia, ekspansi perkebunan kelapa sawit terus berlanjut. Bahkan, laju kecepatan ekspansi perkebunan kelapa sawit terus meningkat dari tahun ke tahun (lihat Tabel 1).
Tabel 1. Laju kecepatan ekspansi perkebunan kelapa sawit di Desa Gunung Sari, Kecamatan Tabang,

Kabupaten Kutai Kartanegara, 2018

\begin{tabular}{|c|c|c|c|}
\hline \multirow[b]{2}{*}{ Tahun } & \multicolumn{3}{|c|}{ Ekspansi Perkebunan Kelapa Sawit } \\
\hline & Luas (Ha) & $\begin{array}{c}\text { Durasi Waktu } \\
\text { (th) }\end{array}$ & $\begin{array}{c}\text { Laju ekspansi } \\
\text { (Ha/th) }\end{array}$ \\
\hline 1990 & 0,0 & 0 & 0 \\
\hline 1995 & 0,0 & 5 & 0 \\
\hline 2000 & 51,9 & 5 & 10,4 \\
\hline 2005 & 73,1 & 5 & 14,6 \\
\hline 2009 & 489,0 & 4 & 122,2 \\
\hline 2016 & 3576,5 & 7 & 510,9 \\
\hline
\end{tabular}

Tabel 1 menunjukkan bahwa laju kecepatan ekspansi perkebunan kelapa sawit paling tinggi adalah mulai tahun 2009 menuju ke tahun 2016 dimana ekspansi perkebunan kelapa sawit dilakukan oleh petani dan perusahaan perkebunan kelapa sawit yang beroperasi di Desa Gunung Sari.Bahkan,dilakukan di area-area yang tutupan lahan semula adalah hutan sehingga mengakibatkan deforestasi (lihat Gambar 1).

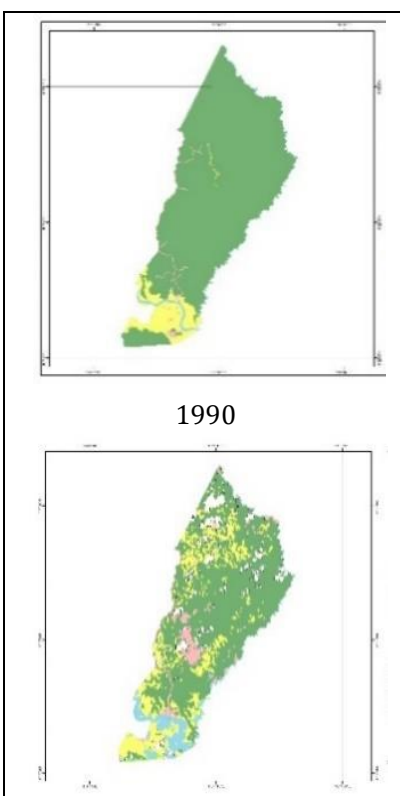

2005

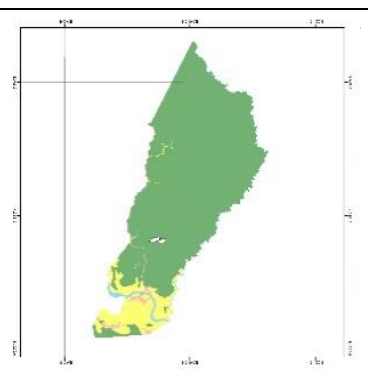

1995

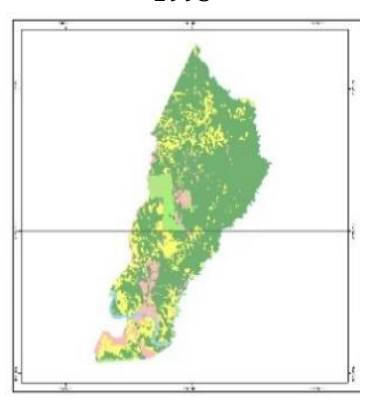

2009

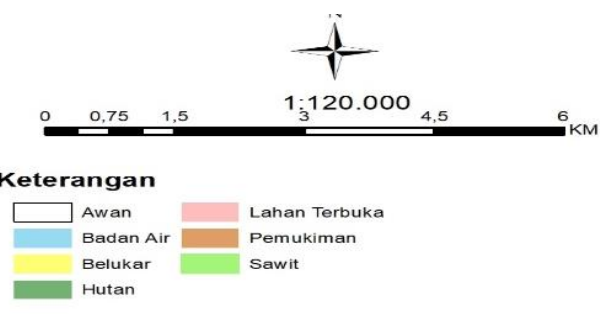

$1: 120.000$

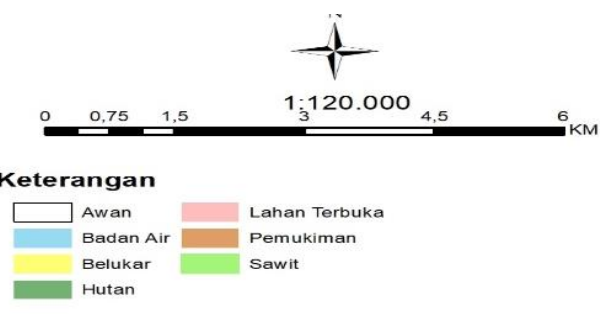

Legenda

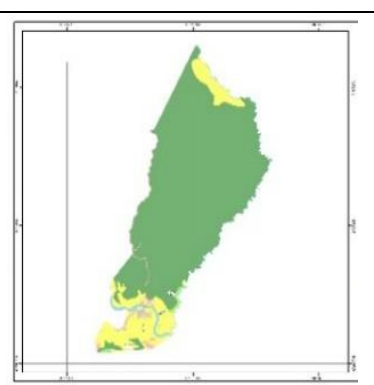

2000

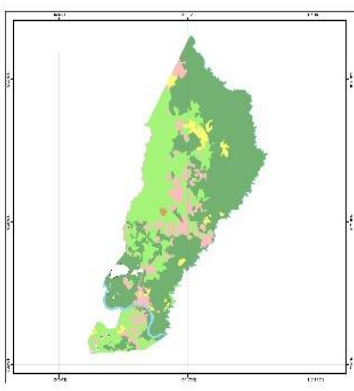

2016

Gambar 1. Perubahan tutupanlahan (land cover) di Desa Gunung Sari, Kecamatan Tabang, Kabupaten Kutai Kartanegara, 2018

Gambar 1 menunjukkan trajektori ekspansi perkebunan kelapa sawit di Desa Gunung Sari yang terjadi melalui lima tahapan yaitu: (1) fase 1990-1995, pada fase ini tidak ada ekspansi perkebunan kelapa sawit di Desa Gunung Sari karena di sekitar Desa Gunung Sari tidak ada perkebunan kelapa sawit swasta yang beroperasi; (2) fase 1995-2000, pada fase ini mulai terjadi 
ekspansi perkebunan kelapa sawit yang dilakukan oleh perkebunan kelapa sawit swasta; (3) fase 2000-2005, pada fase ini ekspansi perkebunan kelapa sawit juga mulai dilakukan oleh petani dengan cara mereplikasi perkebunan kelapa sawit swasta; (4) fase 2005-2009, pada fase ini ekspansi perkebunan kelapa sawit semakin meluas dan terjadi secara lambat karena ekspansi kelapa sawit dilakukan oleh perkebunan kelapa sawit swasta dan petani; (5) fase 2009-2016, pada fase ini ekspansi perkebunan kelapa sawit semakin meluas dan terjadi secara cepat karena ekspansi kelapa sawit dilakukan oleh perkebunan kelapa sawit swasta dan petani. Konsekuensi dari ekspansi perkebunan kelapa sawit yang terus berlanjut yaitu deforestasi yang semakin meluas.

Berdasarkan Gambar 1, dapat disimpulkan bahwa perusahan perkebunan kelapa sawit milik swasta melakukan ekspansi perkebunan kelapa sawit terlebih dahulu kemudian diikuti oleh petani plasma yang mempunyai perkebunan mandiri. Petani plasma yang mempunyai perkebunan mandiri cenderung melakukan ekspansi terlebih dahulu dibandingkan petani mandiri. Ekspansi perkebunan kelapa sawit dilakukan oleh petani plasma yang mempunyai perkebunan mandiri dilakukan setelah ekspansi perusahaan perkebunan kelapa sawit milik swasta karena menunggu ketersediaan dan terbentuknya pasar untuk penjualan TBS. Selain itu, ekspansi perkebunan kelapa sawit dilakukan karena petani merasa tidak bisa mengandalkan bagi hasil plasma saja. Sementara itu, ekspansi perkebunan kelapa sawit dilakukan oleh petani mandiri datang belakangan karena menunggu bestpractices dari petani lain. Artinya, masifnya ekspansi perkebunan kelapa sawit karena adanya stimulasi oleh keberadaan perkebunan kelapa sawit swasta dan didorong oleh adanya pasar lokal yang diciptakan oleh ekonomi kelapa sawit.

Ekspansi perkebunan kelapa sawit dilakukan melalui dua cara yaitu: "hutan-lahan terbukaperkebunan kelapa sawit" dan "hutan-semak belukar-perkebunan kelapa sawit" (lihat Gambar 1). Pembangunan perkebunan kelapa sawit melalui cara "hutan-lahan terbuka-perkebunan kelapa sawit" diindikasikan merupakan cara yang dilakukan oleh perusahaan perkebunan besar kelapa sawit milik swasta. Sementara itu, ekspansi perkebunan kelapa sawit melalui cara "hutansemak belukar-perkebunan kelapa sawit" diindikasikan merupakan cara yang dilakukan oleh perusahaan perkebunan kelapa sawit swasta dan petani kelapa sawit, dimana terdapat tiga tipologi petani kelapa sawit yaitu petani plasma, petani plasma yang mempunyai perkebunan kelapa sawit mandiri dan petani mandiri. Masingmasing tipologi petani mempunyai strategi dalam mengekspansi kelapa sawitnya.

Tabel 2. Strategi ekspansi perkebunan kelapa sawit berdasarkan tipologi petani kelapa sawit di Desa Gunung Sari, Kec. Tabang, Kab. Kutai Kartanegara, 2018

\begin{tabular}{|c|c|c|c|c|}
\hline \multirow[b]{2}{*}{ Strategi Ekspansi } & \multirow[b]{2}{*}{ Variabel } & \multicolumn{3}{|c|}{ Tipologi Petani Kelapa Sawit } \\
\hline & & $\begin{array}{l}\text { Tipe } 1 \text { (Petani } \\
\text { plasma) }\end{array}$ & $\begin{array}{c}\text { Tipe } 2 \text { (Petani plasma yang } \\
\text { mempunyai kebun kelapa } \\
\text { sawit mandiri) }\end{array}$ & Tipe 3 (Petani mandiri) \\
\hline \multirow{3}{*}{$\begin{array}{l}\text { Formal management } \\
\text { driven expansion }\end{array}$} & Skema managemen & Skema PIR & $\begin{array}{l}\text { Skema PIR, PPMD, KKPA, } \\
\text { dan Land ID oleh } \\
\text { perusahaan inti }\end{array}$ & $\begin{array}{l}\text { Skema PIR, PPMD, KKPA, } \\
\text { dan Land ID oleh } \\
\text { perusahaan inti }\end{array}$ \\
\hline & Penyedia modal & Perusahaan inti & $\begin{array}{l}\text { Perusahaan inti, } \\
\text { pemerintah, modal pribadi } \\
\text { dan didukung oleh koperasi }\end{array}$ & $\begin{array}{l}\text { Perusahaan inti, } \\
\text { pemerintah, modal pribadi } \\
\text { dan didukung oleh } \\
\text { koperasi }\end{array}$ \\
\hline & Dukungan aktor & $\begin{array}{l}\text { Perusahaan inti dan } \\
\text { pengurus koperasi }\end{array}$ & $\begin{array}{l}\text { Perusahaan inti, } \\
\text { pemerintah, pengurus } \\
\text { kelompok tani dan } \\
\text { pengurus koperasi }\end{array}$ & $\begin{array}{l}\text { Perusahaan inti, } \\
\text { pemerintah, pengurus } \\
\text { kelompok tani dan } \\
\text { pengurus koperasi }\end{array}$ \\
\hline \multirow{3}{*}{$\begin{array}{c}\text { Social networking } \\
\text { driven expansion }\end{array}$} & Kekuatan jaringan & Cukup & Kuat & Kuat \\
\hline & Banyaknya jaringan & Cukup & Banyak & Banyak \\
\hline & Variasi pasar & Mono market & $\begin{array}{l}\text { Multi market - } 50 \% \text { ke inti } \\
\text { dan } 50 \% \text { ke pasar lokal }\end{array}$ & $\begin{array}{l}\text { Multi market - didominasi } \\
\text { ke pasar lokal }\end{array}$ \\
\hline
\end{tabular}

Tabel 2 menunjukkan bahwa petani plasma yang mempunyai kebun kelapa sawit mandiri merupakan tipologi petani yang mempunyai benefit yang paling tinggi dan paling strategis karena mempunyai banyak "pintu" integrasi dengan perusahaan inti, banyaknya akses modal, jaringan dan pasar dibandingkan dengan tipologi petani plasma dan petani mandiri. Oleh karena itu, tipologi petani plasma yang mempunyai perkebunan kelapa sawit mandiri mempunyai 
banyak peluang untuk melakukan ekspansi perkebunan kelapa sawit di berbagai area yang tutupan lahannya baik hutan atau non hutan dibandingkan dua tipologi petani lainnya (lihat Gambar 2 pada bab berikutnya).

\subsection{Tata Kelola Perkebunan Kelapa Sawit Dan Kaitannya Dengan Tipologi Petani Kelapa Sawit}

Tata kelola perkebunan kelapa sawit khususnya sertifikasi RSPO dan ISPO sampai saat ini masih bersifat suka rela bagi petani. Namun, sertifikasi ISPO sudah diwacanakan akan bersifat wajib bagi petani. Terdapat empat prinsip dan kriteria sertifikasi ISPO bagi patani yaitu: legalitas kebun, organisasi pekebun dan pengelolaan kebun, pengelolaan dan pemantauan lingkungan, dan peningkatan usaha secara berkelanjutan. Sampai saat ini, belum ada petani kelapa sawit baik petani plasma, petani plasma yang mempunyai kebun kelapa sawit mandiri dan petani mandiri di Gunung Sari yang mempunyai sertifikat RSPO atau ISPO walaupun perusahan perkebunan inti yang menjadi mitra petani sudah mempunyai sertifikat RSPO dan ISPO.

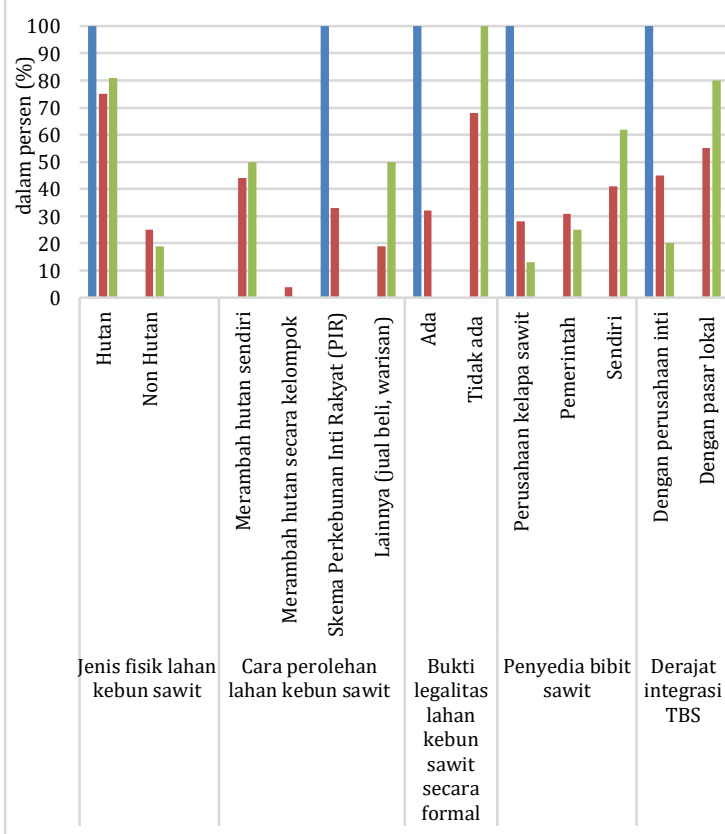

- Tipe 1. Petani plasma

- Tipe 2. Petani plasma yang mempunyai kebun kelapa sawit mandiri Tipe 3. Petani mandiri

Gambar 2. Karakteristik ekspansi perkebunan kelapa sawit berdasarkan tipologi petani kelapa sawit di Desa Gunung Sari, Kec. Tabang, Kab. Kutai Kartanegara, 2018

Tiga tipologi petani kelapa sawit mempunyai dimensi ekspansi yang berbeda-beda (lihat Gambar 2) sehingga masing-masing tipologi petani mempunya tingkat kesiapan implementasi ISPO dan RSPO yang berbeda-beda. Berdasarkan Gambar 2 tersebut dapat disimpulkan bahwa petani plasma dan petani plasma yang mempunyai kebun kelapa sawit mandiri merupakan tipologi yang siap untuk melakukan implementasi ISPO dan RSPO karena adanya integrasi yang cukup kuat dengan perusahaan inti serta kepemilikan legalitas lahan. Sementara itu, petani mandiri kurang siap untuk implementasi RSPO dan ISPO karena terkendala pada ketiadaan legalitas lahan.

Baik petani plasma yang mempunyai perkebunan kelapa sawit mandiri dan petani mandiri menghadapi kendala pada bibit yang tidak bersertifikat, ketiadaan kepemilikan Surat Tanda Daftar Usaha Perkebunan untuk Budidaya (STDB), dan lahan kebun kelapa sawit yang tumpang tindih dengan area konsesi tambang, HGU, HPH dan KBK. Kendala-kendala tersebut mengakibatkan ketidakefektifan implementasi RSPO dan ISPO pada level petani. Berdasarkan hal tersebut dapat disimpulkan bahwa ketidakefektifan tata kelola perkebunan kelapa sawit berdampak pada terus berlanjutnya ekspansi perkebunan kelapa sawit di kawasan hutan dan konflik sosial.

\subsection{Dampak Ekonomi Dari Ekspansi Perkebunan Kelapa Sawit}

Pada masa Pemerintahan Orde Baru, terjadi kegiatan booming pembalakan kayu yang dikenal dengan sebutan jaman 'banjir kap', dimana pemerintah mengijinkan ekspor kayu gelondongan sehingga terjadi eksploitasi hutan besar-besaran di Kalimantan termasuk di Kabupaten Kutai. Setelah masa reformasi, banyak perusahaan HPH yang bangkrut akibat krisis moneter. Kemudian pada sekitar tahun 20052007, melalui program sawit sejuta hektar, Pemerintah Provinsi Kalimantan Timur membuka lahan perkebunan sawit di sejumlah kabupaten di Kalimantan Timur. Adanya program sawit sejuta hektar dan beroperasinya perusahaan perkebunan kelapa sawit telah menstranformasi mata pencaharian masyarakat di Desa Gunung Sari.

Sebelum adanya ekspansi kelapa sawit oleh perusahaan perkebunan kelapa sawit, masyarakat di Desa Gunung Sari bekerja sebagai petani ladang menetap, buruh tebang kayu gelondongan, pekebun karet dan nelayan di Sungai Belayan yang mengalir di sekitar Desa Gunung Sari. Namun, setelah adanya ekspansi perkebunan kelapa sawit oleh perusahaan perkebunan kelapa sawit, masyarakat di Desa Gunung Sari mulai berangsur-angsur mengkonversi semak belukar, ladang dan kebun mereka untuk dijadikan perkebunan kelapa sawit. Konversi lahan tersebut marak dilakukan dilakukan setelah perusahaan perkebunan kelapa sawit empat tahun beroperasi di Desa Gunung Sari. Hal tersebut dilakukan oleh sebagian besar masyarakat di Desa Gunung Sari karena mereka merasakaan dan melihat adanya keuntungan ekonomi dari usaha perkebunan kelapa sawit. 
Usaha pertanian kelapa sawit mendatangkan keuntungan yang besar bagi sebagian rumahtangga di Desa Gunung Sari sehingga mereka dapat mengakumulasi modal yang kemudian diinvestasikan ke usaha lainnya seperti usaha kos-kosan, burung walet dan penyewaan mobil pengangkut Tandan Buah Segar (TBS). Selain itu, masyarakat di Desa Gunung Sari juga menjadi buruh dan staf perusahaan perkebunan kelapa sawit yang beroperasi di sekitar Desa Gunung Sari. Transformasi mata pencaharian tersebut mengakibatkan pendapatan masyarakat di Desa Gunung Sari didominasi dari pertanian sawit dan usaha non pertanian seperti berdagang dan buruh di perkebunan kelapa sawit (lihat Gambar 3).

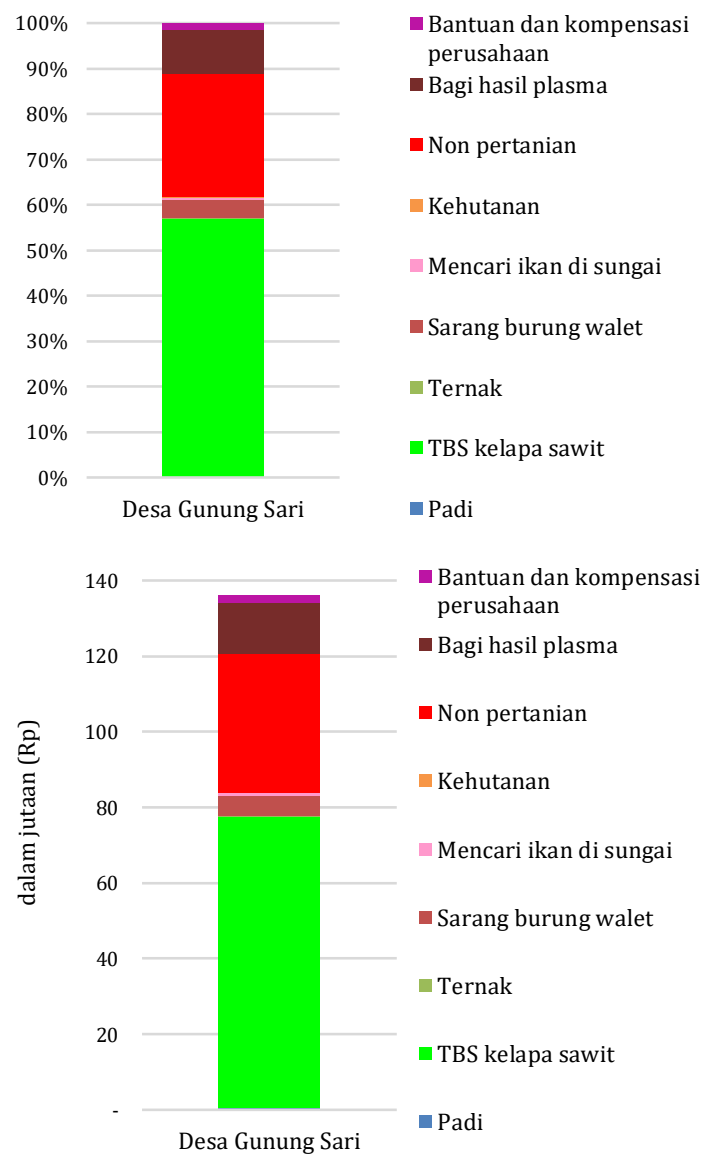

Gambar 3. Rata-rata pendapatan rumahtangga petani per tahun di Desa Gunung Sari, Kecamatan Tabang, Kabupaten Kutai Kartanegara, Kalimantan Timur, 2018

\subsection{Konflik Sosial Akibat Ekspansi Perkebunan Kelapa Sawit: Dapatkah ISPO dan RSPO mengatasinya?}

Variabel resiko sosial berupa konflik diukur melalui persepsi kejadiaan konflik yang terjadi antara petani dengan masyarakat lokal, konflik dengan pemerintah lokal, serta konflik perusahaan perkebunan kelapa sawit. Pengukuran derajat terjadinya konflik dengan memberikan pertanyaan yang diukur melalui skala likert yaitu nilai 1 adalah tidak pernah terjadi konflik dan nilai 4 adalah sangat sering terjadi konflik.

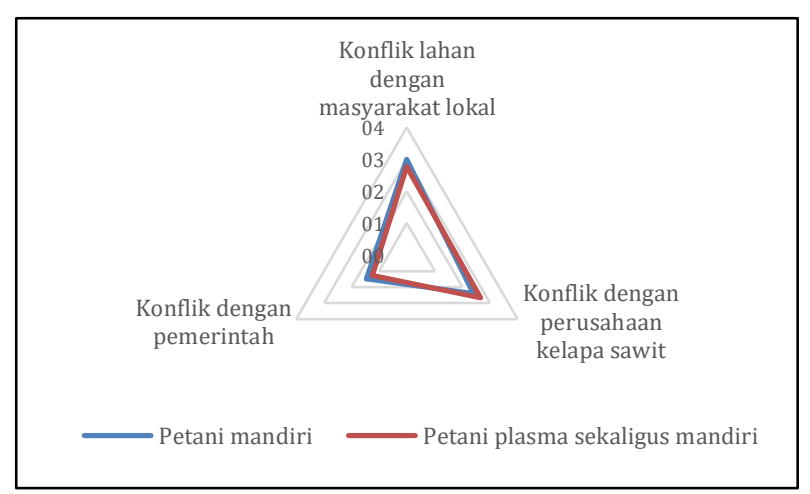

Gambar 4. Persepsi derajat konflik sosial yang terjadi pada petani plasma sekaligus mandiri dan petani mandiri di Desa Gunung Sari, Kecamatan Tabang, Kabupaten Kutai Kartanegara, Kalimantan Timur, 2018

Gambar 4 menunjukkan bahwa petani plasma sekaligus mandiri dan petani mandiri sering terlibat konflik dengan masyarakat lokal dan perusahaan perkebunan kelapa sawit swasta. Konflik yang dialami oleh petani kelapa sawit tersebut mempunyai karakteristik yang berbedabeda tergantung lawan konflik yang dihadapinya. Karakteristik konflik ini dapat dibedakan berdasarkan kedalaman konflik, luasan konflik, dampak konflik dan keterlibatan aktor eksternal komunitas seperti yang diuraikan pada Tabel 3 .

Tabel 3. Karakteristik konflik sosial yang berkaitan dengan perkebunan kelapa sawit di Desa Gunung Sari, Kecamatan Tabang, Kabupaten Kutai Kartanegara, 2018

\begin{tabular}{|c|c|c|c|}
\hline Karakteristik & $\begin{array}{l}\text { Petani Vs } \\
\text { Petani }\end{array}$ & $\begin{array}{c}\text { Petani Vs } \\
\text { Pemerintah }\end{array}$ & $\begin{array}{c}\text { Petani Vs } \\
\text { Perusahaaan } \\
\text { perkebunan } \\
\text { kelapa sawit } \\
\text { swasta } \\
\end{array}$ \\
\hline $\begin{array}{l}\text { Kedalaman } \\
\text { konflik }\end{array}$ & Ketegangan & Desas desus & Demonstrasi \\
\hline $\begin{array}{l}\text { Luasan } \\
\text { konflik }\end{array}$ & $\begin{array}{l}\text { Antar } \\
\text { individu } \\
\text { petani }\end{array}$ & $\begin{array}{l}\text { Petani dengan } \\
\text { ketua RT dan } \\
\text { Kepala Desa }\end{array}$ & $\begin{array}{l}\text { Komunitas } \\
\text { petani dengan } \\
\text { perusahaan } \\
\text { perkebun } \\
\text { kelapa sawit } \\
\text { swasta }\end{array}$ \\
\hline $\begin{array}{l}\text { Dampak } \\
\text { konflik }\end{array}$ & $\begin{array}{l}\text { Timbulnya } \\
\text { kecurigaan } \\
\text { dan } \\
\text { kebencian }\end{array}$ & $\begin{array}{l}\text { Keretakan } \\
\text { hubungan } \\
\text { antara petani } \\
\text { dengan ketua } \\
\text { RT Kepala } \\
\text { Desa }\end{array}$ & $\begin{array}{l}\text { Dominasi dan } \\
\text { pengusiran }\end{array}$ \\
\hline $\begin{array}{l}\text { Keterlibatan } \\
\text { aktor } \\
\text { eksternal }\end{array}$ & Tidak ada & Ada & Ada \\
\hline
\end{tabular}

Konflik yang terjadi antar petani sawit terjadi karena tumpang tindih bukti surat penguasaan lahan yang dikeluarkan oleh RT atau Kepala Desa. Sementara itu, konflik dengan perusahaan perkebunan kelapa sawit swasta, umumnya disebabkan oleh pencemaran lingkungan dan terkait Sisa Hasil Usaha (SHU) plasma serta kebijakan land ID. Pada tahun 2012 terdapat 
konflik antara petani dan RK karena ketidaksepakatan bagi hasil plasma dan penerapan kuota TBS bagi land ID. Konflik terkait bagi hasil plasma yang berlangsung sampai sekarang mengakibatkan para petani plasma mengelola dan memanen sendiri kelapa sawit di area perkebunan plasma. Buah yang dipanen oleh petani dari kebun plasma kemudian dijual ke perusahaan perkebunan inti menggunakan land ID lahan kebun swadaya yang belum menghasilkan buah atau kebun swadaya yang masih belum memenuhi kuota TBSnya atau land ID "abal-abal". Perusahaan perkebunan inti telah berusaha menyelesaikan konflik tersebut dengan mendatangkan mediator seperti Dinas perkebunan dan kehutanan, tetapi sampai saat ini belum menemukan "titik terang". Berdasarkan hal tersebut, dapat disimpulkan bahwa walaupun perusahaan perkebuna inti sudah mendapatkan sertifikasi RSPO dan ISPO, tetapi masih terjadi konflik dengan petani plasma sekaligus mandiri dan petani mandiri. Dapat dikatakan bahwa sertifikasi RSPO dan ISPO belum efektif menekan terjadinya konflik sosial.

\subsection{Dampak Perubahan Ekologi Akibat Perkebunan Kelapa Sawit}

Ekspansi perkebunan kelapa sawit telah mengakibatkan perubahan tutupan lahan hutan yang berdampak pada perubahan ekologi suatu kawasan. Pengukuran derajat perubahan ekologi diukur melalui skala likert yaitu nilai 1 adalah tidak pernah terjadi konflik dan nilai 5 adalah sangat sering.

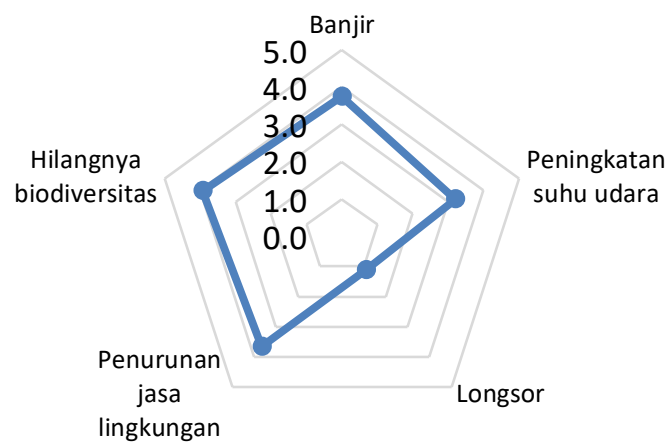

Gambar 5. Persepsi derajat perubahan ekologi yang terjadi di Desa Gunung Sari, Kecamatan Tabang, Kabupaten Kutai Kartanegara, Kalimantan Timur, 2018

Gambar 5 menunjukkan bahwa ekspansi perkebunan kelapa sawit telah berdampak pada perubahan suhu udara, banjir, hilangnya biodiversitas dan jasa lingkungan. Namun, tidak berdampak pada terjadinya longsor.

\section{Perubahan suhu udara}

Perubahan tutupan lahan dari hutan menjadi perkebunan kelapa sawit telah meningkatkan eksposure terhadap matahari sehingga berdampak pada suhu udara menjadi semakin berubah panas.

\section{Seringnya banjir}

Pada tahap landclearingmaka fungsi tutupan hutan hilang. Tutupan hutan mempunyai fungsipenyimpanan air secara alami dan melindungi tanah dari erosi akibat air hujan. Setelah tutupan hutan berubah menjadi calon lahan perkebunan kelapa sawit maka erosi tanah dan banjir pun terjadi. Erosi tanah terjadi ketika air hujan jatuh ke tanah secara langsung tanpa ada kanopi daun-daun pohon yang menjadi pelindung, sehingga air hujan membawa material tanah secara langsung ke daerah lebih rendah dan sungai yang berdampak pada warna air sungai menjadi coklat dan luapan air sungai ke area pemukiman penduduk. Banjir yang terjadi di area pemukiman penduduk akibat dari luapan air sungai terjadi semakin sering setelah banyaknya ekspansi perkebunan kelapa sawit. Bahkan, pada tahun 2005, banjir besar terjadi di Desa Gunung Sari.

\section{Hilangnya biodiversitas}

Perubahan tutupan lahan menjadi perkebunan kelapa sawit yang sifatnya monoculturemenjadikan tumbuhan obat, buah, dan sayur hutan menjadi hilang serta hewan-hewan hutan seperti rusa, beruang, dan orang hutan menjadi semakin berkurang.

\section{Penurunan jasa lingkungan}

Penurunan jasa lingkungan mengakibatkan masyarakat di Desa Gunung Sari susah mencari sayur, hewan buruan, buah-buahan dihutan serta ikan di sungai karena ketersediaan sayur, hewan buruan, buahbuahan di hutan serta ikan di sungai mulai berkurang.

\section{Simpulan}

Ekspansi perkebunan kelapa sawit pada tahun 1990-2005 cenderung berjalan secara lambat, sedangkan pada tahun 2005-2016 ekspansi kelapa sawit cenderung berjalan secara cepat. Ekspansi perkebunan kelapa sawit yang dilakukan oleh petani kelapa sawit plasma yang mempunyai perkebunan kelapa sawit mandiri dan petani mandiri karena distimulasi keberadaan perusahaan perkebunan kelapa sawit swasta dan didorong atas adanya pasar ekonomi lokal kelapa sawit.

Dampak ekonomi akibat ekspansi perkebunan kelapa sawit yaitu terjadinya transformasi mata pencaharian rumahtangga petani dari petani ladang, pekebun karet dan nelayan berubah menjadi petani perkebunan kelapa sawit yang kemudian mengakibatkan dominasi persentase nafkahnya dari usaha pertaniankelapa sawit. Selain itu, ekspansi perkebunan kelapa sawit berdampak pada tingginya frekuensi konflik sosial khususnya 
konflik antar petani dan petani dengan perusahaan perkebunan kelapa sawit. Maraknya ekspansi kelapa sawit juga berdampak pada ekologi khususnya pada perubahan tutupan lahan hutan yang mengakibatkan perubahan suhu udara, hilangnya biodiversitas, banjir, erosi tahan dan jasa lingkungan. Dampak negatif dari ekspansi perkebunan kelapa sawit tersebut belum bisa ditekan karena ekspansi yang dilakukan oleh beberapa rumahtangga petani khususnya petani plasma yang mempunyai lahan perkebunan kelapa sawit mandiri dan petani mandiri tumpang tindih dengan area konsesi tambang, HGU, HPH dan KBK. Hal tersebut terjadi karena ketidakefektifan implementasi sistem tata kelola perkebunan kelapa sawit pada level petani yang kemudian berdampak pada berlanjutnya ekspansi perkebunan kelapa sawit di kawasan hutan dan non APL.

\section{Saran}

Hasil penelitian menunjukkan bahwa terdapat pasar lokal yang bisa menampung TBS yang diusahakan oleh petani kelapa sawit di lahan yang tidak bersertifikat dan berada kawasan hutan serta lahan yang tumpang tindih dengan konsesi tambang, HGU dan HPHsehingga menjadikan ekspansi kelapa sawit terus berlanjut. Oleh karena itu, untuk ke depannya RSPO dan ISPO juga harus diterapkan di semua rantai nilai produk kelapa sawit terutama tingkat tapak yaitu petani kelapa sawit. Penerapan RSPO dan ISPO pada petani kelapa sawit ini membutuhkan dukungan finansial yang kuat dari berbagai lembaga sehingga perlu peran pemerintah dalam penyediaan dukungan finansial tersebut. Selain itu, perlunya sosialisasi dan pendampingan kepada petani kelapa sawit untuk memastikan implementasi RSPO dan ISPO di tingkat petani berjalan dengan lancar.

Permasalah keterlanjuran tumpang tindih lahan kebun kelapa sawit petani dengan area KBK, konsesi tambang, HGU, dan HPH harus dicarikan jalan keluar oleh pemerintah melalui skemaskema yang ada misalnya Tanah Objek Reforma Agraria (TORA), perhutanan sosial atau skema lainnya. Sementara itu, keterlanjuran penanaman bibit kelapa sawit yang tidak bersertifikat atau "cabutan" oleh petani harus dicarikan solusi oleh pemerintah melalui skema-skema allternatif agar petani dapat memproses sertifkasi ISPO.

\section{DAFTAR PUSTAKA}

Afriyani D., Kroeze C., Saad A., 2016. Indonesia palm oil production without deforestation and peat conversion by 2050. Science of the Total Environment 557-558 (2016) 562-570

Amalia R. 2016. Perubahan lanskap ekologi, kerentanan dan resiliensi nafkah rumahtangga petani di sekitar hutan di Kalimantan Timur.[tesis]. Bogor [ID]: Institut Pertaian Bogor.

Bennett A., Ravikumar A., Cronkleton P. 2018. The effects of rural development policy on land rights distribution and land use scenarios: The case of oil palm in the Peruvian Amazon. Land Use Policy 70 (2018) 84-93

Denzin N.K., Lincoln Y.S., 2000. Handbook of qualitative research. California: Sage pulication

Fitzherbert E.B., Struebig M.J., Morel A., Danielsen F., Bruhl C.A., Donald P.F., Phalan B. 2008. How will oil palm expansion affect biodiversity?. CE Press: Trends in Ecology and Evolution Vol.23 No.10

[Gapki] Gabungan Pengusaha Kelapa Sawit Indonesia. 2017. Refleksi industru kelapa sawit 2016 dan prospek 2017. [internet]. Jakarta: Gapki

Gatto M., Wollni M., Qoim M. 2015. Oil palm boom and land-use dynamics in Indonesia: the role of policies and socioeconomic factors. Land use policy 46 (2015) 292-303. Elsevier Science, Ltd. UK

Giessen L., Burns S., Sahide M.A.K., Wibowo A. 2016. From governance to government: the strengthened role of the state bureaucracies in forest and agricultural certification. Policy and society 35 (2016) 71-89

Hidayah N. 2016. Perubahan lanskap ekologi taman nasional Tesso Nilo dan sistem sosial ekonomi masyarakat lokal akibat ekspansi kelapa sawit di Riau. [tesis].Bogor: Institut Pertanian Bogor

[ISPO] Indonesian Sustainable Palm Oil. 2017. Sertifikasi ISPO. [internet]. [diunduh 2017 September 3]. Tersedia pada http://www.ispo.org/sertifikasi

Irawan S., Tacconi L., Ring I. 2013. Stakeholders' incentives for land-use and REDD+ : the case of Indonesia. Ecological economic 87 (2013) 75-83. Elsevier Science, Ltd. UK

[Kemenperin RI] Kementrian Perindustrian Republik Indonesia. 2007. Gambaran sekilas industry minyak kelapa sawit. [internet] Jakarta: Kementrian Perindustrian

Khatun R., Reza M. I. H., Moniruzzaman M., Yaakob Z. 2017. Sustainable oil palm industry: The possibilities. Renewable and Sustainable Energy Reviews 76 (2017) 608-619

Koczberski, G., Curry, G.N. 2005. Making a living: land pressure and changing livelihood strategies among oil palm settlers in Papua New Guinea. Agricultural system 85 (2005) 324-339

Koh L.P., Wilcove D.S. 2008. Is oil palm agriculture really destroying tropical biodiversity? Conservation letters vol. 1. Issue 2 June 2008 (6064)

Mardianingsih D.I.T. Dharmawan A.H., Kolopaking L.M., Firdaus M., Nielsen M.R. 2018. Livelihood transformation of rural communities: A livelihood system analysis of the Dayak Punan of Berau District, East Kalimantan, Indonesia. Journal of Economics and Sustainable Development Vol 9, No. 18, 2018

[RSPO] Roundtable on Sustainable Palm Oil. 2017. About proportion of oil palm globally certified by RSPO. [internet]. [diunduh 2017 Mei 31]. Tersedia pada http://www.rspo.org/about/impacts

Ruysschaert D., Salles D. 2014. Towards global voluntary standards: questioning the effectiveness in attaining conservation goals the case of the rountable on sustainable palm oil (RSPO). Ecological economic 107 (2014) 438-446

Schouten G., Bitzer V. 2015. The emergence of Southern standards in agricultural value chains: a new 
trend in sustainability governance?. Ecological economic 120 (2015) 175-184

Setiawan E.N., Maryudi A., Purwanto R.H., Lele G., 2016. Opposing interests in the legalization of nonprocedural forest conversion to oil palm in Central Kalimantan, Indonesia. Land use policy 58 (2016) $472-481$

Susanti A., Maryudi A. 2016. Development narratives, notions of forest crisis, and boom of oil palm plantations in Indonesia. Forest policy and economics 73 (2016) 130-139

Wicke B., Sikkema R., Dornburg V., Faaij A. 2011. Exploring land use changes and the role of palm oil production in Indonesia and Malaysia. Land Use Policy 28 (2011) 193-206
Widiono, S. 2008. Pembangunan perkebunan kelapa sawit serta dampaknya terhadap pelapisan sosial dan strategi nafkah: kasus dua desa Sawah EtnisSerawai dan Jawa di Kabupaten Seluma, Provinsi Bengkulu. [tesis]. Bogor[ID]: Sekolah pascasarjana Institut pertanian Bogor

Yulian B.E., Dharmawan A.H., Soetarto E., Pacheco P. 2017. Dilema nafkah rumahtangga pedesaan sekitar perkebunan kelapa sawit di Kalimantan Timur. Sodality: Jurnal Sosiologi Pedesaan Vol 5 No. 3 Desember 2017 hal 242-249

Zunariyah S. 2012. Dilema ekspansi perkebunan kelapa sawit di Indonesia: Sebuah tinjauan sosiologi kritis. Pusat Dokumentasi dan Informasi Ilmiah UNS https://eprints.uns.ac.id/id/eprint/132 